\title{
Pemberdayaan Keluarga Melalui Pendampingan Budidaya "Empon-Empon" Serta Produksi Dan Branding Karak Non “Bleng”
}

\author{
Lila Pangestu Hadiningrum ${ }^{1}$, Syarah Ayu Nur Annisa ${ }^{2}$
}

${ }^{1}$ Fakultas Syariah/ Intitut Agama Islam Negeri Surakarta/ Jl. Pandawa, Dusun IV/Sukoharjo

${ }^{2}$ Fakultas Ekonomi dan Bisnis /Institute Agama Islam Negeri Surakarta/ Jl. Pandawa, Dusun IV/Sukoharjo

Email:lilahadiningrum@gmail.com

\begin{tabular}{ll}
\hline Article submitted & $:$ Februari 2021 \\
Review article & $: 24$ Maret 2021 \\
Article received & $: 30$ Maret 2021 \\
\hline
\end{tabular}

\begin{abstract}
Abstrak
Pandemi Corona Virus 19 berdampak terhadap keseluruhan aspek kehidupan, khususnya ketahanan ekonomi keluarga dengan ditandai adanya menurunnya produksi, distribusi, pendapatan dari home industry Tujuan kegiatan ini adalah memberdayakan keluarga melalui budidaya empon- empon serta membranding karak non "bleng berbasis kearifan lokal di Dusun Nglaroh, Nangsri, Kebakkramat, Karanganyar. Metode pendekatan pada kegiatan ini adalah rural development and empowerment melalui penyampaian materi, diskusi, latihan praktik (drill practice) serta pendampingan. Sasaran kegiatan ini adalah kelompok produktif ekonomi yang terdiri dari 10 home industri dan kelompok masyarakat non produktif ekonomi yang berjumlah 30 keluarga. Indikator kegiatan ini adalkah peningkatan pengetahuan dan ketrampilan dalam budidaya empon - empon dan pengetahuan dan keteampilan dalam pengelolaan kerak non bleng sebagai produk unggulan serta partisipasi peserta dalam kegiatan. Instrument yang dipakai adalah ceklist pre dan post. Adapun hasil kegiatan ini adalah adanya peningkatan pengatahuan, ketrampilan serta partisipasi masyarakat terhadap aspek kegiatan ini sebesar $90 \%$. Ketahanan ekonomi keluarga dapat diperbaiki melalui pemberdayaan kelompok degan budidaya emponembpon dan branding kerak belng pada masyarakat ekonomi produktif dan non preoduktif di desa Ngangsi Kebak kramat Karanganyar Jawa Tengah
\end{abstract}

Kata Kunci: pemberdayaaan; rural;development; ketahanan; ekonomi

\section{Abstract}

Corona Virus 19 pandemic has impact on all aspects of life, especially family economic resilience. This condition are specific sign as decreases in production and distribution, income from home industry. This community services aims to empower families through empon-empon cultivation and branding "karak nonbleng" based on local wisdom in Nglaroh village, Nangsri, Kebakkramat, Karanganyar. Services Community activatioan used rural development and empowerment approach by knowledge session, discussion, practice training (drill practice) and mentoring. The target was of 10 home industries and non-productive economic community groups totaling 30 families. Achivement indikator on this activation were increased of knowledge and skills in empon-empon cultivation and knowledge and skills in the management of non-bleng crust as a superior product and participated of participants in activitied. The instruments used pre and post checklists. Result of this activity were increased in knowledge, skill and community participation in this aspect of the activity by $90 \%$. Family economic resilience can be improved through group empowerment by cultivating empon- embpon and back-crust branding in productive and non-productive economic communities in the village of Ngangsi Kebakkramat Karanganyar, Central Java

Keywords: empowerment; rural; development;resilience; economy

\section{PENDAHULUAN}

Di awal tahun 2020, wabah coronavirus atau Covid-19 mulai masuk di Indonesia. Pandemi Covid-19 telah berhasil merombak segala aspek kehidupan masyarakat, salah satunya adalah sektor ekonomi 
masyarakat. Aspek ekonomi atau aspek finansial merupakan aspek utama yang terpenting dalam masyarakat. Aspek finansial adalah sumber utama dalam kehidupan sehari - hari masyarakat. Dalam aspek ekonomi, finansial dijadikan sebagai sumber penghidupan masyarakat bisa berupa uang ataupun barang - barang yang memiliki nilai. Hadirnya virus Covid-19 di Kabupaten Karanganyar, utamanya pada Dusun Nglaroh, Desa Nangsri, sangat mempengaruhi ekonomi masyarakat sekitar.

Adanya penutupan akses atau pembatasan sosial, mengakibatkan laju ekonomi masyarakat semakin melambat. Sehingga, tingkat kesejahteraan masyarakat (daya jual dan daya beli) turut melemah. Dusun Nglaroh merupakan dusun yang unggul dalam produksi karak. Karak merupakan kerupuk khas Jawa yang sering dikenal dengan kerupuk nasi atau kerupuk gendar. Kerupuk gendar merupakan jenis olahan dari beras yang merupakan warisan leluhur masyarakat Jawa yang hampir punah. (Kusdarianto \& Mukhlisa, 2018). Oleh sebab itu perlu adanya pengembangan dan pemberdayan pada home industry karak di Dusun Nglaroh Desa Nangsri, di masa pandemi untuk mendongkrak produktivitas dan pendistribusian karak serta pembentukan usaha kesehatan bersama masyarakat melalui pemberdayaan dan pendampingan budidaya apotik hidup dalam polybag sebagai upaya dalam mempertahankan ekonomi keluarga.

\section{ANALISIS SITUASI}

\section{Gambaran Umum}

Desa Nangsri merupakan desa yang terletak di Kecamatan Kebakkramat, Kabupate karanganyar, Jawa Tengah. Desa ini memiliki luas wilayah 252 hektare dan terdapat 10 dusun didalamnya. Desa Nangsri berbatasan dengan Desa Pulosari dibagian utara, Desa Brujul disisi selatan, Desa Kemiri disebelah barat dan Desa Macanan dibagian timur. Dusun Nglaroh merupakan salah satu dusun yang terdiri dari $1 \mathrm{rw}$ dan $2 \mathrm{rt}$. Jumlah penduduk di Rt 01 Rw 06 sebanyak 87 kepala keluarga dengan total 230 jiwa. Sedangkan jumlah penduduk di Rt 02 Rw 06 sebanyak 60 kepala keluarga dengan total hanya 170 jiwa saja.

Dusun Nglaroh merupakan salah satu dusun di Desa Nangsri yang unggul dalam produksi karak. Selain itu, topologi wilayah ini dikelilingi dengan persawahan dan perlintasan kereta api disisi utara. Dusun Nglaroh diapit oleh dua suguhan pemandangan Gunung Lawu disisi Timur serta Gunung Merapi dan Gunung Merbabu disisi Barat. Sebagian besar masyarakat bekerja sebagai petani.

\section{Permasalahan}

Setelah melewati beberapa tahapan yakni observasi (pengamatan) dan diskusi dan koordinasi dari potensi potensi yang ada. Maka beberapa identifikasi masalah, antara lain bidang ekonomi yaitu menurunnya pendapatan keluarga dan menurunnya produksi dan distribusi karak

\section{Solusi Sasaran}

Upaya yang dilakukan untuk mengatasi peramasalahan diatas adalah pembentukan kelompok usaha berbasis masyarakat yaitu pendampingan budidaya empon-empon serta pengembangan produk karak tanpa bleng.

\section{METODE}

Kegiatan pemberdayaan keluarga melalui pendampingan budidaya "empon-empon" serta produksi dan branding karak non "bleng" ini merupakan upaya pengabdian masyarakat berbasis riset "Kerso Darma" KKN transformative penulis dengan tim masyarakat. Adapun identitas sasarannya adalah kelompok masyarakat non produktif ekonomi yaitu masyarakat desa yang terdiri dari 30 keluarga serta masyarakat produktif ekonomi yaitu 10 home industry karak. Adapun metode kegiatan ini menggunakan pendekatan rural development and empowerment (Pengembangan dan pemberdayaan masyarakat desa). Pendekatan ini diawali dengan perencanaan partisipatif yaitu suatu tahapan proses pemberdayaan masyarakat yang dimulai dengan tahap kajian keadaan secara partisipatif yang didapat dari informasi yang dikumpulkan. Perencanaan partisipatif bermanfaat bagi masyarakat untuk mengarahkan kegiatan atau program tersebut (Hadiwijoyo, 
2012). Berkaitan dengan hal tersebut ciri-ciri perencanaan partisipatif adalah sebagai berikut: terfokus pada kepentingan masyarakat, partisipatoris, dinamis, sinergitas, legalitas dan fisibilitas. Partisipatif merupakan komponen penting dalam pembangkitan kemandirian dan proses pemberdayaan (Hikmat, 2010).

Menurut Masita, E. D., Maimunah, S., \& Abidah, S. N. (2020) Proses pemberdayaan keluarga dilakukan melalui kegiatan fasilitasi keluarga agar mampu menganalisa situasi yang ada di lingkungannya, mencari pemecahan masalah berdasarkan kemampuan dan keterbatasan yang mereka miliki, mengembangkan usahanya dengan segala kemampuan dan sumber daya yang dimilikinya sendiri dan mengembangkan sistem untuk mengakses sumber daya yang diperlukan (Winarni, 2013).

Pemberian materi dan latihan praktik (drill practice) digunakan sebagai metode dalam pelaksanaan pendampingan ini. Kegiatan ini dilaksanakan mengingat masyarakat masih banyak yang belum mengetahui pentingnya apotik hidup dan produksi serta branding karak non Bleng. Berdasarkan pendapat (Sudjana, 2011) metode drill adalah satu kegiatan melakukan hal yang sama, berulang-ulang secara sungguh- sungguh dengan tujuan untuk menyempurnakan suatu keterampilan agar menjadi permanen.

Indikator capaian hasil kegiatan pemberdayaan keluarga melalui pendampingan budidaya "emponempon" serta produksi dan branding karak non "bleng" ini dapat dilihat dari keberhasilan budidaya (pertumbuhan dan hasil) dari empon-empon, serta keberlanjutan program.

Instrument yang digunakan untuk mengukur keberhasilan pemberdayaan keluarga adalah cek list observasi dan kuesioner wawancara.

Adapun indikator ketercapaian/hasil pendampingan budidaya “empon-empon” kelompok masyarakat non produktif ekonomi meliputi: pengetahuan masyarakat tentang kesehatan, imunitas, lingkungan dan budidaya empon-empon, Peningkatkan kepedulian dan respon masyarakat terhadap perlunya peningkatan ketahanan keluarga dan prosentase peningkatan kemandirian masyarakat. Adapun indikator ketercapaian/hasil produksi dan branding karak non "bleng" masyarakat produktif ekonomi yaitu 10 home industry karak meliputi: Pengetahuan masyarakat tentang produksi karak non bleng, Peningkatkan kepedulian dan respon masyarakat terhadap kesehatan pangan, pengetahuan dalam labeling, pengemasan dan branding, pengetahuan marketing online, serta peningkatkan kemandirian masyarakat berwirausaha berwawasan lingkungan. Adapun uji analisisnya menggunakan diskriptif sebelum adanya pendampingan dan setelah pendampingan.

\section{HASIL DAN PEMBAHASAN}

Kegiatan pemberdayaan keluarga melalui pendampingan budidaya "empon-empon" serta produksi dan branding karak non "bleng" ini keberhasilan dan keberlanjutan program diukur dari hasil dari setiap kriteria indicator yang dicapai masyarakat.

Hasil pengabdian masyarakat yang disajikan dalam bagian ini adalah hasil keberhasilan pendampingan budidaya "empon-empon" dan keberhasilan produksi dan branding karak non "bleng"

\section{Pemberdayaan dan pendampingan budidaya empon- empon}

Tabel 1 Indikator ketercapaian hasil pendampingan budidaya "empon-empon"

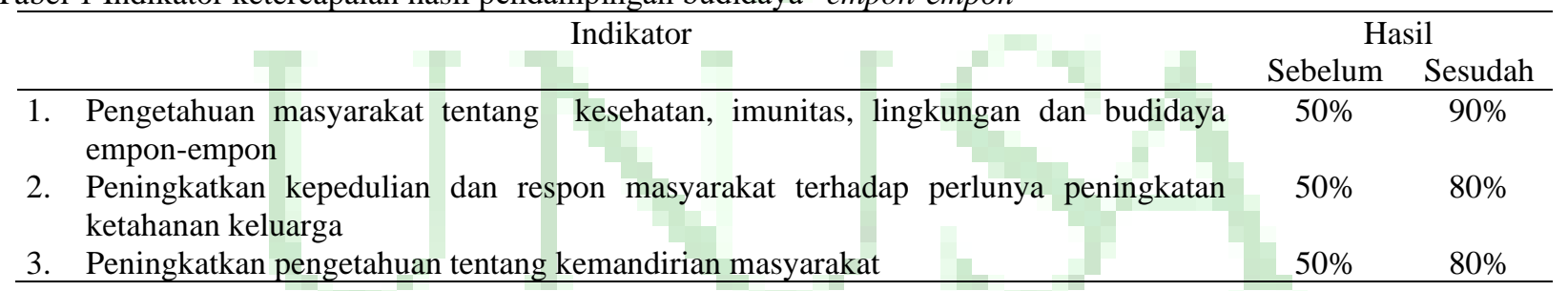

Berdasrakan tabel 1 sebagian besar kelompok sasaran didapatkan peningkatan pengetahuan sebesar $40 \%$, peningkatan kepedulian sebesar 30\% serta penongkatan pengetahuan kemandirian masyarakat sebear $40 \%$ dan telah terbentuknya kelompok kesehatan bersama masyarakat empon- empon Tahapan dalam proses pemberdayaan meliputi: seleksi lokasi, sosialisasi pemberdayaan masyarakat dan proses pemberdayaan 
masyarakat (Mardikanto \& Soebianto, 2017). Dari hasil seleksi dan observasi lokasi ditemukan keterbatasan lahan di Dusun Nglaroh, Desa Nangsri, Kebakkramat, Karanganyar. Kegiatan dilanjutkan dengan sosialisasi program dan pelaksanaan program. Sosialasi program dilakukan dalam bentuk kelompok-kelompok untuk menghindari banyaknya kerumunan di masa pandemi. Setelah adanya sosialisasi program ke masyarakat, tim melakukan pendampingan (Masita et al., 2019). Sosialisasi dan pendampingan diawali dengan sosialisasi terhadap protokol kesehatan di masa pandemi kemudian praktek pembudidayaan tanaman apotek hidup atau Empon-Empon. Seperti diungkapkan oleh (Sholihah, 2020) bahwa lahan pekarangan yang dikelola secara optimal dapat memberikan manfaat bagi rumah tangga atau keluarga yang mengelolanya. Lahan pekarangan yang dikelola dengan baik dapat memberikan manfaat antara lain adanya peningkatan gizi keluarga, tambahan pendapatan keluarga, lingkungan rumah asri, teratur, indah dan nyaman. Lahan atau tempat penanaman tanaman apotek hidup atau empon-empon dalam pendampingan keluarga ini disiasati dengan bertanam pada polybag. Selain polybag, tim pendampingan juga memanfaatkan barang - barang bekas semisal botol plastik, plastik kemasan minyak goreng dan plastik atau bungkus susu bubuk. Pembudidayaan empon-empon sebagai jamu/rempah-rempah khas Indonesia diharapkan mampu meningkatkan imunitas dalam kondisi pandemi. Jenis tanaman yang dipilih untuk dibudidayakan adalah jahe, serai, kencur, kunyit, daun meniran dan cabai merah. Diplihnya budidaya empon - empon, diharapkan memberikan kemanfatan seperti antioksidan, anti inflamasi, meningkatkan imunitas tubuh, dan lain sebagainya
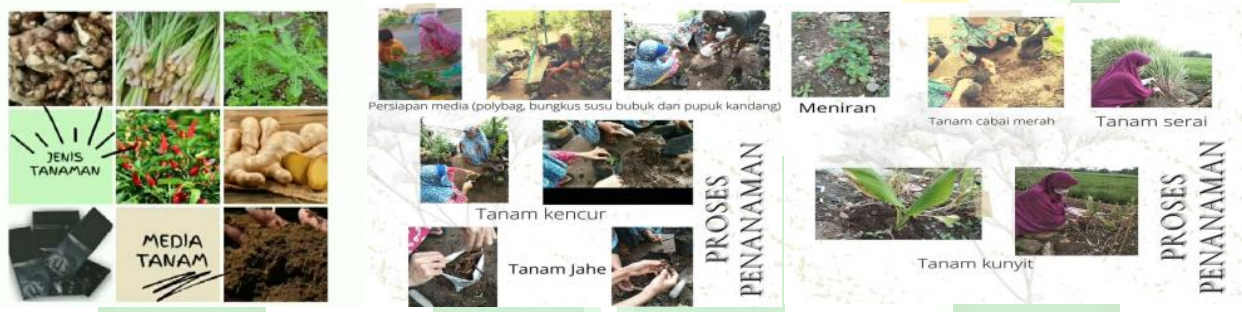

Gambar 1. Persiapan media taman dan proses penanaman empon-empon

\section{Produksi dan branding karak non "bleng"}

Tabel 2 Indikator ketercapaian/hasil produksi dan branding karak non "bleng"

\begin{tabular}{llcc}
\hline & \multicolumn{1}{c}{ Indikator } & Sebelum & Setelah \\
\hline 1. & Pengetahuan dan ketrampilan masyarakat tentang produksi karak non Bleng & $40 \%$ & $90 \%$ \\
2. & Peningkatkan kepedulian dan respon masyarakat terhadap kesehatan pangan & $40 \%$ & $90 \%$ \\
3. & Pengetahuan dalam labeling, pengemasan dan Branding & $20 \%$ & $70 \%$ \\
4. Pengetahuan dalam marketing secara online & $10 \%$ & $30 \%$ \\
5. & Peningkatkan kemandirian masyarakat dalam kewirausahaan berwawasan & $50 \%$ & $70 \%$
\end{tabular}

Berdasarkan tabel 2 dijelaskan bahwa ada peningkatan pengetahuan dan ketrampilan dalam produksi sebsar 50\%, respon ketahanan panganan 50\%, pengemasn dan baranding 50\%, online marketing 20\% serta kemandirian kewirausaan sebesar 20\% Dikemukakan oleh (Supardan, 2020) bahwa rendahnya pengetahuan dan kesadaran konsumen (masyarakat) mengenai bahaya boraks dan formalin bagi kesehatan menyebabkan tidak adanya upaya preventif dari masyarakat untuk memilih makanan yang ada di pasaran. Selain itu, banyaknya nama lain dari boraks (pijer, bleng, obat gendar, cetitet, obat puli, Sode, obat lontong) membuat masyarakat tidak sadar bahwa bahan yang mereka gunakan adalah boraks.

Bleng atau borak digunakan dalam proses pembuatan kerupuk (karak) untuk mengembangkan dan mengenyalkan adonan gendar. Selain itu, bleng atau borak juga akan menghasilkan aroma dan cita rasa khas (getir). Bila menggunakan bleng atau borak, tekstur gendar akan menjadi bagus dan hasilnya akan mengembang saat digoreng. Zat yang terkandung dalam bleng atau borak berfungsi sebagai pengawet dan pengeras gendar (Hartati, 2018). Penggunaan tepung tapioka digunakan sebagai pengganti bleng dalam fungsi untuk merenyahkan karak. Tapioka merupakan bahan campuran pada pembuatan kerupuk. Berfungsi sebagai tepung substitusi untuk memperkecil ketergantungan pada tepung terigu. Tapioka mengandung 
adalah amilosa dan amilopektin yang berfungsi untuk menyerap air selama pemasakan sehingga produk akhir menjadi renyah (Hariyati, 2018). Bahan tambahan pangan dalam pembuatan krupuk lempeng sebenarnya bisa menggunakan bahan yang lebih aman bagi kesehatan seperti hasil penelitian (Hijrati, 2014) menyatakan bahwa variasi penambahan tepung tapioca sebagai bahan pengganti bleng (boraks) menghasilkan kerupuk gendar dengan sifat fisik warna, aroma dan tekstur kerupuk gendar dengan tambahan tepung tapioca tidak berbeda dengan penambahan bleng, yaitu kerupuk gendar dengan penambahan tepung tapioca $25 \%$.

Karena pembuatan karak tidak menggunakan bleng atau borak, maka bahan yang digunakan dalam proses pendampingan ini hanya bawang putih, garam, tepung tapioka dan beras. Langkah pertama adalah membuat gendar dari nasi. Mula - mula, cuci beras yang telah disediakan hingga bersih. Kemudian mencampurkan bumbu - bumbu yang telah dihaluskan, seperti bawang putih dan garam. Setelah itu, campurkan dengan tepung tapioka secukupnya, lalu kukus. Angkat gendar yang telah matang, untuk ditumbuk hingga halus. Hasil tumbukan itu kemudian ditekan - tekan pada tempat yang datar. Biasanya, ada wadah khusus untuk dijadikan sebagai cetakan. Biasa berbentuk balok dengan sisi atas yang terbuka. Biarkan kukusan tadi dingin dengan sendirinya. Setelah dingin, barulah gendar diiris tipis - tipis. Setiap produsen karak di Dusun ini memiliki anyaman bambu yang digunakan untuk alas penjemuran gendar. Hasil irisan tipis tadi, kemudian ditata pada anyaman bambu tersebut lalu dijemur. Penjemuran biasa dilakukan di tempat terbuka (halaman rumah) agar gendar langsung terkena sinar matahari. Terakhir adalah proses penjemuran yang hampir memakan waktu tiga hari akibat hujan yang terus menerus. Sembari menunggu proses penjemuran,dilakukan pembuatan label kemasan.

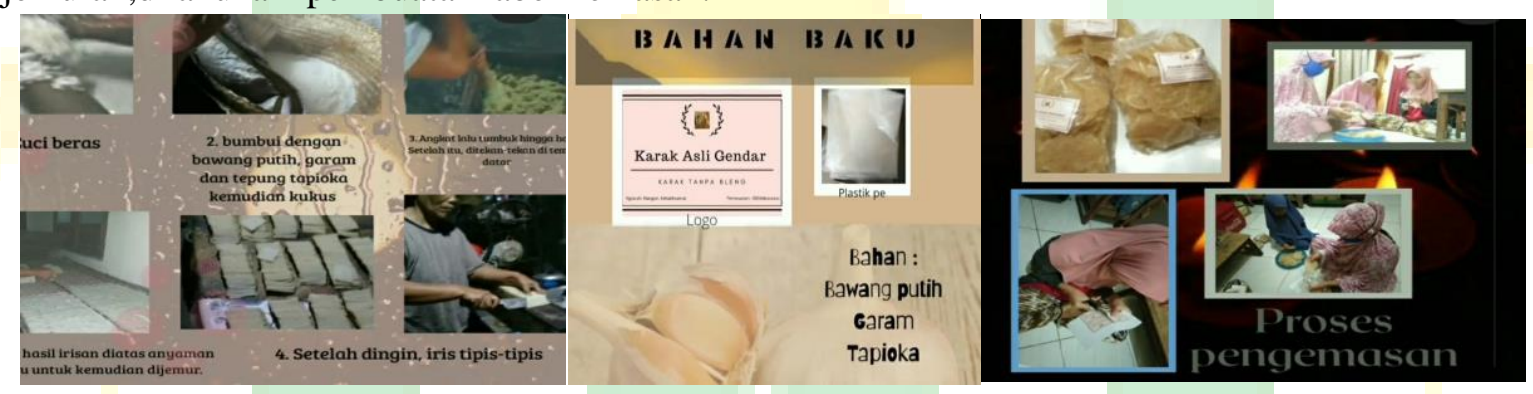

Gambar 3. Pendampingan produksi karak non bleng,

Untuk menarik daya beli masyarakat, pengemasan karak dilakukan tim dengan modifikasi. Branding sangat diperlukan untuk menarik minat pembeli. Merek merupakan aset yang menciptakan value bagi pelanggan dengan memperkuat kepuasan dan loyalitas. Merek menjadi "alat ukur" bagi kualitas value yang ditawarkan" (Kartajaya, 2014). Hal ini dikarenakan produk branded (bermerk) selalu mendapatkan ruang khusus di hati para konsumen. Dalam pendampingan keluarga ini proses branding tidak menggunakan plastik "kresek", melainkan plastic PE yang sedikit tebal. Dalam kemasan pun ditambahkan label atau logo produsen. Dalam pendampingan, pemberdayaan keluarga ini selain menjual karak yang telah digoreng, juga akan menjual karak - karak yang mentah. Karak dipasarkan selain offline juga secara online melalui media website, facebook dan instagram. Pelatihan penggunaan teknologi informasi untuk memperluas jaringan pemasaran sangat penting untuk dilalakukan seperti diungkapkan oleh (Setyowati \& Iskandar, 2019) bahwa Facebook marketing adalah melakukan aktivitas marketing menggunakan semua fasilitas yang disediakan oleh facebook dengan tujuan meningkatkan penjualan (sales) dan menjalin komunikasi yang lebih langgeng dengan pelanggan (customer relationship). Tujuannya untuk memperluas distribusi penjualan di tengah pembatasan aktivitas masyarakat. 


\section{KESIMPULAN DAN SARAN}

Adanya pendampingan pemberdayaan keluarga melalui branding karak tanpa Bleng dan pembentukan UMKM empon- empon mampu meningkatkan ketahanan ekonomi keluarga Saran perlu adanya kegiatan follow up khususnya branding dan marketing karak non bleng dan tanaman empon-empon secara online.

\section{UCAPAN TERIMAKASIH}

Terima kasih diucapkan kepada warga Dusun Nglaroh, Desa Nangsri serta LP2M IAIN Surakarta yang telah mendukung pendampingan ini.

\section{REFERENSI}

Hadiwijoyo, S. S. (2012). Perencanaan Pariwisata Perdesaan Berbasis Masyarakat (Sebuah Pendekatan Konsep). Graha Ilmu.

Hariyati, N. (2018). Kerupuk Lemi Bebas Boraks Kajian Dari Dosis Natrium Tripolyphospat Yang Berbeda.

Hartati, F. K. (2018). Alternatif Pengganti Boraks Pada Pembuatan Kerupuk Puli. Heuristic - Jurnal Teknik Industri, 15(2), 51.

Hijrati, N. (2014). Variasi Penambahan Tepung Tapioka Sebagai Pengganti “Bleng” (Boraks) Dalam Pembuatan Kerupuk Gendar Ditinjau Dari Sifat Fisik, Organelopatik dan Masa Simpan. Poltekes Yogyakarta.

Hikmat, H. (2010). Strategi Pemberdayaan Masyarakat. Humaniora Utama Press.

Kartajaya, H. (2014). On Brand (Seri 9 Elemen Marketing). Mizan.

Kusdarianto, I., \& Mukhlisa, A. N. (2018). Pemberdayaan Masyarakat Melalui Pembuatan Kerupuk Gendar Sebagai Usaha Skala Rumahan Dalam Meningkatkan Kesejahteraan Di Desa Malangke Kec. Malangke Kab. Luwu Utara. Resona Jurnal Ilmiah Pengabdian Masyarakat, 2(1).

Mardikanto, T., \& Soebianto, P. (2017). Pemberdayaan Masyarakat dalam Perspektif Kebijakan Publik. Alvabeta.

Masita, E. D., Maimunah, S., \& Abidah, S. N. (2019). Pemanfaatan Rumah Keluarga Sebagai Kedasi (Kedai Support Asi) Menuju Zero Susu Formula Pada Bayi Usia 0-6 Bulan. Jurnal Pengabdian Masyarakat IPTEKS, 5(1), 13-21.

Masita, E. D., Maimunah, S., \& Abidah, S. N. (2020). Implementasi Kawasan Zero Susu Formula dengan Kedasi (Kedai Support Asi) di Kelurahan Wonokromo Surabaya. JPM17: Jurnal Pengabdian Masyarakat, 5(01), 01-06.

Setyowati, S., \& Iskandar, E. (2019). PKM Industri Krupuk Lempeng di Bantul. Jurnal ABDIMAS Unmer Malang, 4(2).

Sholihah, R. (2020). Pemberdayaan Masyarakat Melalui Pemanfaatan Pekarangan Sebagai Warung Hidup Keluarga Di Desa Kutamandiri Kecamatan Tanjungsari. Kumawula: Jurnal Pengabdian Kepada Masyarakat, 3(2).

Sudjana, N. (2011). Penilaian Hasil dan Proses Belajar Mengajar. Rosda Karya.

Supardan, D. (2020). Pelatihan Pembuatan Alat Deteksi Sederhana Boraks Dan Formalin. Transformasi: Jurnal Pengabdian Masyarakat. Jurnal Transformasi.

Winarni, T. (2013). Peran Pendamping dalam Pengembangan Posdaya dalam buku Merajut Kesejahteraan di Arus Lokal. Azzagrafika. 